\title{
都市域への影響の高いスギ花粉放出源の推定
}

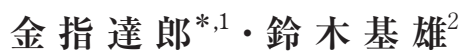

\begin{abstract}
著者らが開発したスギ花粉飛散予報モデルを応用して, 首都圈への寄与度の高いスギ花粉放出源の推定を試みた。評価の指 標として, 花粉飛散期間中の平均花粉濃度と, 花粉濃度と当該地域の人口の積（花粉暴露指標とする）の二つを用いた。花粉 放出源を含まない狭いターゲット領域（東京駅を中心とした半径 $10 \mathrm{~km}$ の円内, 領域内人口 500 万人強）を対象にした場合に はいずれの指標でも類似した結果であった。一方, 広域首都圈（東西約 $90 \mathrm{~km}$, 南北約 $80 \mathrm{~km}$, 領域内人口約 3,000 万人）を 対象とした場合には花粉濃度を指標に用いると, その内部にある花粉放出源メッシュの効果が非常に強く推定された。また, 推定対象年によって推定結果が異なった。そのため, 花粉放出源対策地域の優先順位選定にこの手法を適用する際には, 複数 年の結果を総合的に判断することが重要であると考えられた。 キーワード：スギ花粉症, 花粉飛散予報モデル, 花粉放出源, 首都圈
\end{abstract}

\begin{abstract}
Tatsuo Kanazashi", and Motoo Suzuki ${ }^{*}$ (2010) Special Issue "For Countermeasures against Sugi Pollinosis in Forest Science", The Estimation of the Pollen Source Areas of Cryptomeria japonica D. Don which Have High Contributions to the Japanese Metropolitan Region. J. Jpn. For. Soc. 92: 298-303. By using a predicting model for pollen dispersal of Cryptomeria japonica, which was developed by the present authors, we estimated the Cryptpmeria pollen source areas which have the high contributions to the Japanese metropolitan region. For the evaluation criteria, we used two indices; the average pollen concentration during pollen dispersal period, and the pollen exposure index (pollen concentration multiplied by the population in that area). For the smaller target region which did not contain any pollen source (the region within the $10 \mathrm{~km}$-circle around Tokyo Station, with the population of more than five million people), the similar results were obtained when using both indices. However, for the greater Metropolitan region (90 km from east to west and $80 \mathrm{~km}$ from north to south, including Tokyo and Yokohama city, with the population of 30 million people), the pollen sources within this region were estimated to have the extremely high contributions to this region when using the pollen concentration as the evaluation criterion. Moreover, the results of different sample years differed from each other, for both indices for evaluation criteria.
\end{abstract}

Key words: Japanese cedar pollinosis, predicting model for pollen dispersal, pollen source area, Metropolitan region

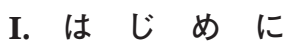

スギ花粉症 (堀口・斎藤, 1964) は 1970 年代後半からそ の初発患者が急激に増加し（斎藤，1999）,「国民病」と呼 ばれるようになってから久しい。2008 年現在，スギ花粉症 患者数は全国民の $26 \%$ に達すると推計されており, 近年に 至ってもなお増加し続けている（馬場・中江, 2008)。こう した状況の中, スギ花粉症対策として, 医療・予防面の対 応, 花粉飛散予報の高度化等に加えて, 花粉放出量そのも のを低減させる対策（いわゆる花粉放出源対策）が強く求 められている。

放出源対策には，間伐等の施業あるいは薬剂等の散布に より花粉生産抑制を目指すものと, 皆伐して少花粉スギ(田 島, 2001 ; 津田, 2007) や無花粉スギ（平ら, 1993 ; 平, 2006 ; 斎藤, 2008）等の植栽あるいは樹種転換するものに 大別される。しかし，450万 ha（林野庁，2009）に及ぶ 広大なスギ林全体を対象に漫然と対策を実施しても，すぐ には効果が期待できない。そのため, 人口集中地域への主 要な花粉供給源を推定し，まずその地域に対策を集中する
ことが効率的であると考えられる。

ところで, 著者らは 1997〜2002 年に実施された文部科 学省プロジェクト「スギ花粉症克服に向けた総合研究」に おいて, 地域ごと, 時間単位のスギ花粉飛散予報を目指し た「スギ花粉飛散量数值予報モデル」(以下, 単に「花粉 飛散予報モデル」という）を開発し（鈴木, 2003), その 後も随時改良を重ねてきた(鈴木, 2007)。後述するように, このモデルを応用することにより, ある地点（メッシュ） に飛来した花粉がどこからどのくらい飛来したのかを推計 することが可能となる。

本報告では, 花粉飛散予報モデルを用いて, 最大の人口 集中域である首都圈への影響度の高いスギ花粉放出源を推 定した事例について紹介する。あわせて，この手法を適用 して放出源対策を優先的に実施する地域を選定する際に留 意すべき点について検討した。

\section{II. スギ花粉飛散予報モデル}

\section{1. モデルの概要}

このモデルは, 花粉放出源モデル, 局地気象モデル, 移

\footnotetext{
*連絡先著者 (Corresponding author) E-mail : kana@ffpri.affrc.go.jp

1独立行政法人森林総合研究所 † 305-8687 つくば市松の里 1 (Forestry and Forest Products Research Institute, 1 Matsunosato, Tsukuba 3058687, Japan)

${ }^{2}$ 財団法人気象業務支援センター † 101-0054 東京都千代田区神田錦町 3-17 東ネンビル（Japan Meteorological Business Support Center, 3-17 Kandanishiki-cho, Chiyoda-ku, Tokyo 101-0054, Japan)

(2010 年 3 月 5 日受付; 2010 年 10 月 12 日受理)
} 
流拡散モデルの三つのサブモデルで構成される。この花粉 飛散予報モデルの詳細については別途報告する予定である が，概略は以下のとおりである。

花粉放出源モデルは, 全国花粉放出源分布とその推移予 測（家原・宮本, 2002; 金指, 2003）, 雄花生産量予測（横山・ 金指，2001），雄花開花時期の予測（金指·横山，2002； Kanazashi and Yokoyama, 2005) および花粉放出量予測（有 沢, 2000)を実行するモデルである。放出源モデルによって， 各花粉放出源（メッシュ）における林外への花粉放出量が 1 時間単位で推定される。局地気象モデルは, 気象庁が提 供する気象デー夕格子点予報值（GPV）から，より詳細な 局地における值を推定する。移流拡散モデルは，放出源か ら大気中に放出された花粉が刻々と変化する気象場をどの ように移流，拡散していくかを記述する。今回の花粉飛散 予報モデルでは，この部分にラグランジュ型モデル，すな わちモデル内で花粉に見立てた模擬粒子を発生させ，その 挙動を計算，追跡する方式を採用した。

この花粉予報モデルの最も重要な特徵は, 特定の放出源 メッシュと特定のターゲットメッシュ間の花粉の受け渡し を各時点での気象場と花粉放出状況とから推計し, それら のすべてのペアを統合して各ターゲットメッシュでの花粉 飛散状況を推定することであるといえる。この特徴を利用 することにより, 以下で述べるように, ターゲットメッシュ に飛来した花粉の放出源を推定することが可能になる。

\section{2. モデルによる花粉放出源推定手法}

この予報モデルは，花粉放出源モデルで放出源メッシュ ごとの花粉放出量を時単位で計算し，それに見合った量の 模擬花粉を計算機内のモデル上で大気中に放出させ，局地 気象モデルで推定された気象場を移流拡散モデルで拡散さ せて各地（ターゲットメッシュ）での花粉濃度を推計する。 したがって，あらかじめ飛散させる模擬花粉にその放出源 メッシュの座標（マーカー）を付与しておけば, ターゲッ トメッシュに飛来した花粉の放出源を把握, 集計すること が可能になる。

計算にあたってのメッシュサイズは，放出源，ターゲッ 卜ともに 2 倍 3 次メッシュ(およそ $2 \mathrm{~km}$ 四方)とした。ター ゲット領域はターゲットメッシュの集合として任意に設定 可能である。ターゲット領域への寄与度の高い放出源推定 の対象範囲は東北地方南部から中部地方に至る約 $600 \mathrm{~km}$ 四方とした（図-1）。また，対象年は，全国的なスギ花粉 豊作年にあたる 2005 年と関東地方における準豊作年だっ た 2008 年とした。調査対象期間は，東京都品川における ダーラム型花粉捕集器による花粉飛散量計測值（10日間 移動平均值）が 30 個 $/ \mathrm{cm}^{2}$ を超える期間とした。この期間 は, 2005 年では 3 月 3 日〜 月 14 日， 2008 年では 2 月 28 日〜3 月 29 日であった。なお， 1 日間当たり 30 個 $/ \mathrm{cm}^{2}$ と いう計測值は, このタイプの捕集器での花粉モニタリング や花粉飛散予報で，一般に「多い」というランクの下限值 として用いられている值である。

以上の方法で, 首都圈に流入する花粉量の指標（後述）
に対する寄与度を発生源メッシュごとに推計した。

\section{3. モデルの花粉飛散予報精度}

本研究の「都市域への寄与度の高い花粉放出源」の推定 結果を直接検証する手だては, 現時点ではない。そのため, この結果の信頼度はひとえに花粉飛散予報モデルの予測精 度にかかっているといえる。そこで, 結果に最も大きく影 響すると考えられる花粉飛散最盛期における予測值と実測 值の比較事例を図-2に示した。花粉濃度測定地点（夕ー ゲットメッシュ）として, 東京都の花粉情報事業（とう きょう花粉ネット, http://www.fukushihoken.metro.tokyo. $\mathrm{jp} / \mathrm{kanho} / \mathrm{kafun} /$ ）の公開データから, 花粉放出源に比較 的近い立川と離れた杉並の測定值を借用した。実測デー夕 が得られたのは 2008 年のみである。

両測定地点とも, 予測值と実測值の変動パターンはお子小 むね一致している（図-2）。予測值と実測值間には有意な 正の相関が認められたが，相関係数はさほど高くはなかっ

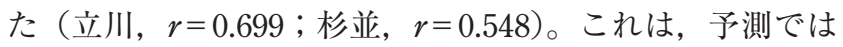
鋭く高いピークであったのに対し現実には緩く比較的長時 間継続するピークであった場合や，ピークの高さが異なる 場合などがあったためである(図-2)。また, モデルが小ピー クの出現を予測したが現実には花粉の飛散が現れなかった 場合もみられるが（立川の 3 月 13 日 19：00 頃など)，こ れは予測の空間的なズレを反映していた可能性がある。し かし, 少なくとも花粉飛散最盛期については, この予報モ デルは巨視的な経時パターンを比較的良く再現できている とみなすことができると考える。

先に述べたこのモデルの特徵から考えると，モデルの予 測精度が高い場合には, 大半の放出源-ターゲット間のペア において，花粉の受け渡しが一定の精度で推定されている はずである。したがって，下記の手法で花粉放出源を推定 する際の精度は, 定量的に示すことは困難であるが, 第一 義的には花粉飛散予報の精度に規定されると考えられる。

\section{III. ターゲット領域に流入する花粉量の指標}

\section{1. 花粉 濃 度}

花粉飛散予報モデルの最終的出力は各ターゲットメッ シュにおける花粉濃度である。そのため, ターゲットメッ シュに流入する花粉量の指標としては花粉濃度（調查対象 期間の平均濃度）を用いるのが自然であり，また理解しや すい。すなわち，あるターゲットメッシュに流入した花粉 濃度 $\left(\right.$ 個 $\left./ \mathrm{m}^{3}\right)$ のうち, ある花粉放出源メッシュからどれ だけの量が寄与したか $\left(\right.$ 個 $\left./ \mathrm{m}^{3}\right)$ を評価する指標である。 ある花粉放出源の夕ーゲットの花粉濃度への寄与度を, 以 下では「寄与濃度」と呼ぶことにする。ターゲット領域と しては以下の 2 とおりについて検討した。

一つめは東京駅を中心とした半径 $10 \mathrm{~km}$ の円内である (図-1の青色の円内)。この領域内には 500 万人強の人口 が居住するが，昼間人口はこれよりも大幅に増加すると考 えられる。また，この領域内にはまとまった花粉放出源は 皆無であった（家原ら，2000）。 
しかし, 約 3,500 万人といわれる首都圈人口に比べてこ のターゲット領域はあまりにも狭いと考えられる。そこ で二つめとして, 首都圈をより広くカバーするため, 図一 1 の青色の枠で示した東西約 $90 \mathrm{~km}$, 南北約 $80 \mathrm{~km}$ の矩形 領域（西側 E 139.1875, 東側 E 140.3125, 南側 N 35.2583, 北 側 N 36.0250）を対象とした。この領域には東西では八王 子市〜千葉市を，南北ではさいたま市大宮～湘南地方まで を含み, 約 3,000 万人，つまり首都圈人口の大半をカバー する。ただしこの中には花粉放出源が比較的多いメッシュ も含まれている（図-1）。

\section{2. 花粉暴露指標}

比較的広域のターゲット領域を対象にする場合には，そ の領域内には人口密度の疎密がある。とくに領域内に花粉 放出源を多く抱えるメッシュではそこに居住する住民は非 常に少ない場合があると想定される。こうしたメッシュで

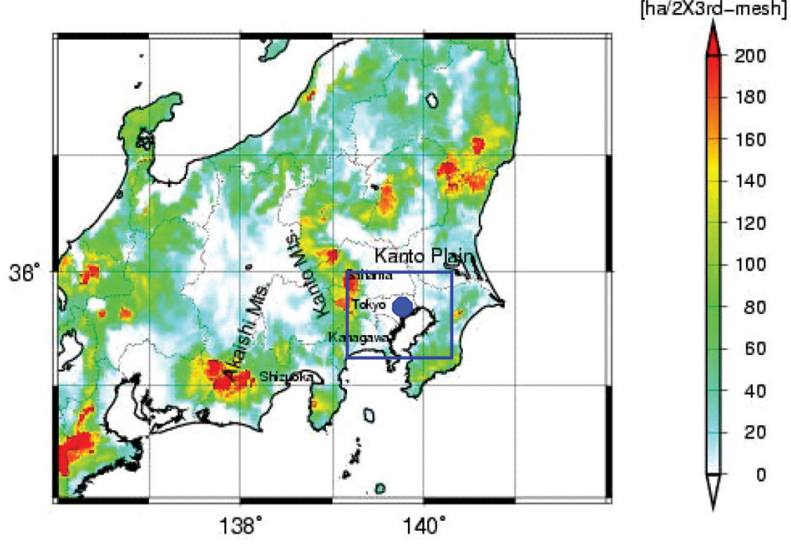

図-1. 関東地方周辺におけるスギ花粉放出源 (26 年生以 上のスギ人工林）の分布

2 倍 3 次メッシュ（約 $2 \mathrm{~km}$ 四方）当たりの面積割合を表示した。 赤く表示された部分はメッシュの $50 \%$ 以上がスギ花粉放出源であ ることを示す。また，青色の円とより広域の矩形領域は，ターゲッ 卜領域として解析した範囲を表す。
は飛散する花粉濃度は非常に高くなる可能性があるが，こ のメッシュに居住する人が暴露される花粉の総量は, 人口 の多いメッシュに比べて必ずしも多いとは限らない。

このような実態を考慮するために，その領域の住民が暴 露される花粉量の指標として, 人口分布を考慮した花粉濃 度，すなわち花粉濃度と人口の積（以下，花粉暴露指標と する)を定義した。ある場所に飛んでくる花粉の量よりも， そこにいる人間がどれだけ多くの花粉に接するかの方が, 実用的な花粉症対策としては有用である。暴露指標は，た とえば 100 人が居住するあるターゲットメッシュの住民全 員が 10,000 個ずつの花粉を浴びた場合と，他のメッシュ に居住する 10,000 人が 100 個ずつの花粉を浴びた場合に は同じ值となる。

しかし，このままでは単位が人口（人）×花粉濃度（個 $\left./ \mathrm{m}^{3}\right)$ となるため, 結果をそのまま花粉濃度を指標とした ときの寄与度 (寄与濃度) と比較検討できない。そのため, 得られた結果をターゲット領域全体の平均人口で除して基 準化して表現することにした。この場合には単位は濃度と 同じく個 $/ \mathrm{m}^{3}$ となる。花粉曝露指標への各放出源メッシュ の寄与度 $\left(D_{i j}\right)$ は，下記の（1)式で計算される。

$$
D_{i j}=\frac{\sum_{l m}\left(C_{i j}^{l m} \times P_{l m}\right)}{\sum_{l m}\left\{P_{l m} /\left(l_{\max } \times m_{\max }\right)\right\}}
$$

ここで, $C_{i j}^{l m}$ はメッシュ $i, j$ (放出源メッシュの座標) の ターゲットメッシュ $l, m$ (ターゲットメッシュの座標) へ の花粉濃度を指標とした寄与度 $\left(\right.$ 個 $\left./ \mathrm{m}^{3}\right), P_{l m}$ は夕ーゲッ トメッシュ $l, m$ の人口, $l_{\max } \times m_{\max }$ は夕ーゲットの全メッ シュ数である。すなわち分母はターゲット領域のメッシュ 当たりの平均人口を表している。以下ではこの值 $\left(D_{i j}\right)$ を「人口分布を考慮した寄与濃度」と呼ぶことにする。

メッシュごとの人口データは平成 12 年度国勢調查抒よ
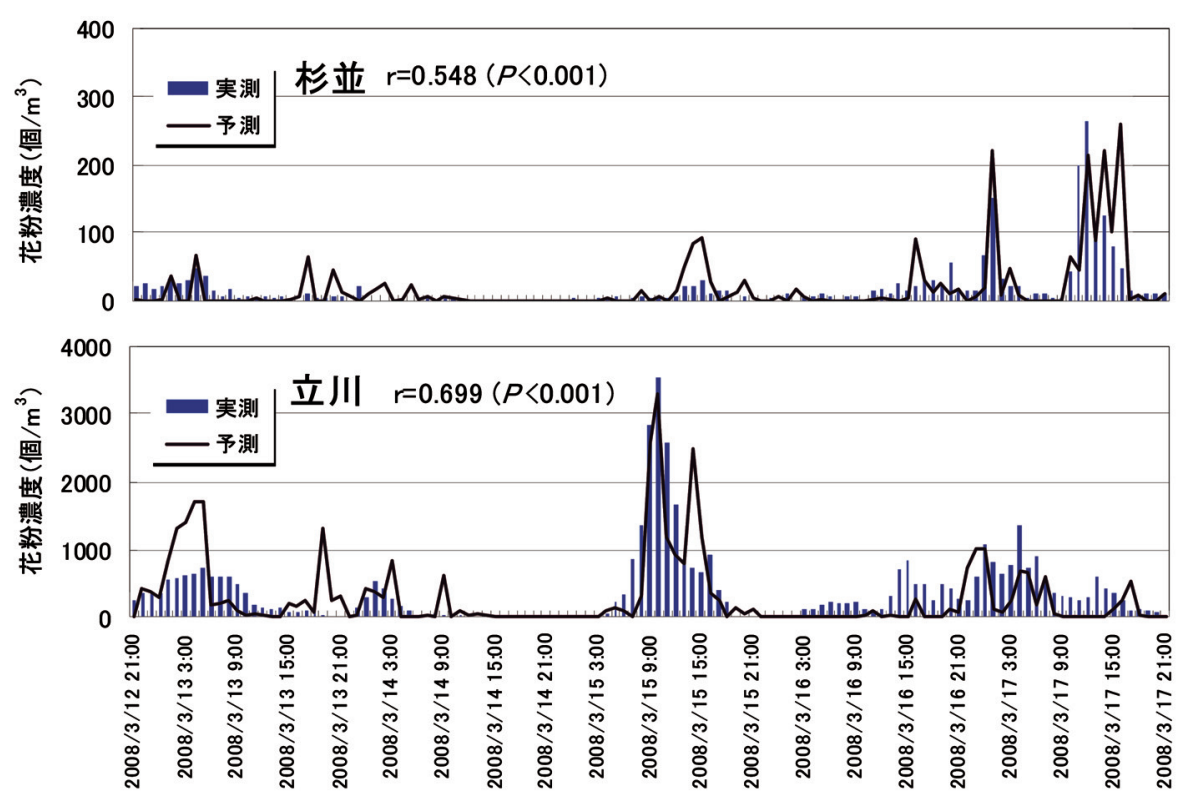

図-2．花粉飛散予報モデルによる花粉 濃度予測結果と実測值の比較 （2008 年花粉飛散最盛期の事例） 
び平成 13 年度事業所・企業統計調査等のリンクによる地 域メッシュ統計（統計情報研究開発センター, 2005）を適 用した。また，評価対象とするターゲット領域は，上記と 同じく図-1に示した東西約 $90 \mathrm{~km}$, 南北約 $80 \mathrm{~km}$ の矩形 領域とした。

\section{IV. 推定結果と考察}

\section{1. 首都圏周辺の花粉放出源分布}

首都圈周辺におけるスギ花粉放出源分布（2005 年の状 況）を図-1に示す。これは，林業の停滞により伐採が全 く行われないとの想定のもとで，1995年の花粉放出源分 布から齢級分布を 10 年分スライドさせて 2005 年の状況を 推定した結果である（家原・宮本（2002）のデータより作 成）。花粉放出源は， 26 年生以上のスギ人工林とした。

茨城県, 栃木県, 福島県の県境付近 (阿武隈山地南部), 杤木県西部（日光～鹿沼地方周辺）, 群馬県南西部, 埼玉 県西部, 東京都西部（秩父山地〜奥多摩地方）および静岡 県西部に花粉放出源の多いメッシュが多く存在する。それ に次いで, 房総半島南部, 神奈川県西部, 伊豆半島西部お よび山梨県南西部（富士山麓）にも花粉放出源が多い。ま た，首都圈からの距離は遠いが，三重県や岐阜県中部〜西 部, 福井県北部にも花粉放出源の多いメッシュが多いこと がわかる。

\section{2. 寄与濃度の高い花粉放出源}

東京都心部(東京駅を中心とした半径 $10 \mathrm{~km}$ 以内の領域) への各地の花粉放出源の寄与濃度を図-3に示す。

2005 年シーズンでは, 埼玉県西部〜群馬県南西部, 東 京都西部から多くの花粉が流入したと推定された。また, 花粉放出源分布が比較的少ない神奈川県東部, 千葉県北東 部（図-1）からの流入も多かったと推定された。これは, 花粉放出源の分布がさほど多くなくても, ターゲット領域 との距離が近いことによると考えられる。一方，花粉放出 源の比較的多い千葉県南部，伊豆半島方面や茨城県方面か らの流入は少なかった。また, 寄与の程度は高くはないも のの, ターゲット領域から遠い静岡県西部や北陸地方から の流入も検出された。

2008 年シーズンでは, 2005 年と同様, 埼玉県西部や東 京都西部からの流入が多いと推定されたが，千葉県方面や 茨城県南部からの花粉の流入が 2005 年に比べてかなり多 かったことがわかる。また，神奈川県については県西部か らの流入が 2005 年に比して多かったと推定された。一方, 北陸地方からの花粉の流入はほとんど認められなかった。

次に, ターゲット領域を図-1の矩形領域とした場合の, 各地花粉放出源の寄与濃度の推定結果を図-4に示した。 両年の推定結果ともターゲット領域内の花粉放出源を含む メッシュの寄与が非常に強調されている。これは, ターゲッ 卜領域内にある花粉放出源を含むメッシュでは花粉濃度は 非常に高まるが，その花粉の多くはそのメッシュ内の放出 源に由来するためである。すなわち, ターゲット領域の人 口密集地への寄与がたとえ低くても, 領域全体（平均）と
してみた場合には必ず寄与の高いメッシュであると判定さ れることになる。そのため, 広域のターゲット領域を対象 とする場合には，住民が曝露する花粉量への影響を考えた 場合，適切な指標とはいえないと考える。

\section{3. 人口分布を考慮した寄与濃度の高い花粉放出源}

図-1の矩形領域に対する各地の花粉放出源の人口分布 を考慮した寄与濃度を図-5に示す。なお, 都心部を対象 とした結果は示さなかったが, 寄与濃度の推定結果とほと んど同じであった。これは，この領域内では人口密度が非 常に高く，かつその分布が比較的一様であるためである。

図-5を大局的にみると, 都心（東京駅中心の半径 $10 \mathrm{~km}$ 以内）を対象とした場合と類似した結果であった。 すなわち, 両年とも秩父, 奥多摩など関東平野西部の山地 の寄与が高かった。2005 年には北陸からの流入がある程 度認められたのに対し，2008 年はほとんどなかったなど の傾向も両手法で一致していた。また, 千葉県中北部から の寄与が 2005 年よりも 2008 年で高かったことなども共通 した傾向として指摘できる。なお, 図のスケールが対数的 表現であるためややみにくいが, 人口分布を考慮した寄与 濃度のメッシュ平均值は花粉の大豊作年だった 2005 年の 值は 2008 年の 2 倍強であった。

しかし, より詳細に検討すると, 双方の指標で評価した 結果について明らかな違いも指摘できる。最も顕著なのが, 神奈川県東部の寄与度が, 東京都心部を対象とした場合よ り両年とも高く, とくに 2008 年では秩父, 奥多摩地域よ りも寄与度の高い放出源メッシュが多かったと推定された ことが挙げられる。これは, 東京都区部の人口集地域への 距離が近いことに加えて, 都区部に次ぐ人口集中域である 横浜市等への強い寄与が評価された結果であると考えられ る。また, 千葉県全域からの寄与度は 2008 年の方が高い のは都心部を対象とした寄与濃度の推定結果と同様だが, 房総半島南部や伊豆半島からの寄与度の年間差はこの指標 を対象にした方が小さく, 2005 年においてもある程度の 寄与があったと推定された。

\section{4. 実用に用いる場合の問題点}

ここでは，以上で紹介してきた手法で都市域への寄与度 の高い花粉放出源を推定し, 放出源対策を優先的に実施す る地域を選定する際に留意すべき点, あるいは問題点を指 摘したい。

第一は，二つの評価指標の特徵についてである。本報告 では, 東京都心部の花粉曝露指標に対する各地花粉放出源 の寄与度（人口分布を考慮した寄与濃度）を提示しなかっ たが，この圈内では人口密度は非常に高く，かつ比較的一 様とみなされるため, 寄与濃度の推定結果（図-3）とほほ 同様の結果になると考えられる。すなわち, 比較的狭くか つ内部に花粉放出源を含まないターゲット領域を対象にし た場合には，いずれの指標でも同様の結果が得られること になる。

しかし, ターゲット領域を変えれば推定結果が異なる可 能性がある。たとえば，横浜を中心とした場合には寄与濃 

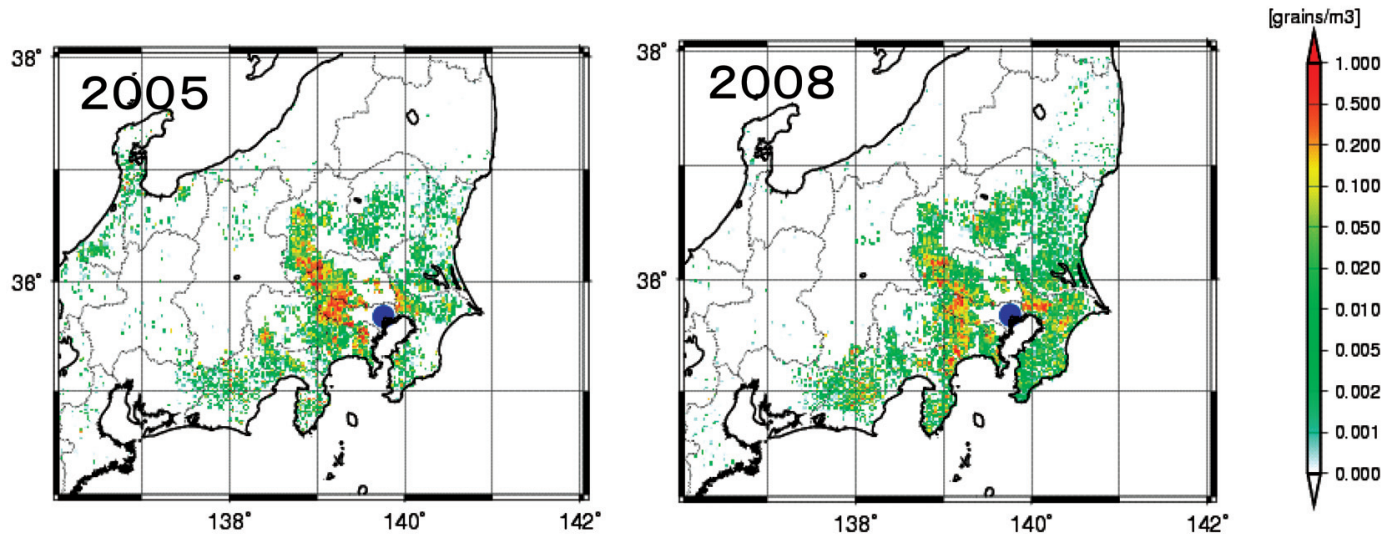

図-3．東京都心（東京駅を中心とした半径 $10 \mathrm{~km}$ の円内）を対象とした寄与濃度の推定結果
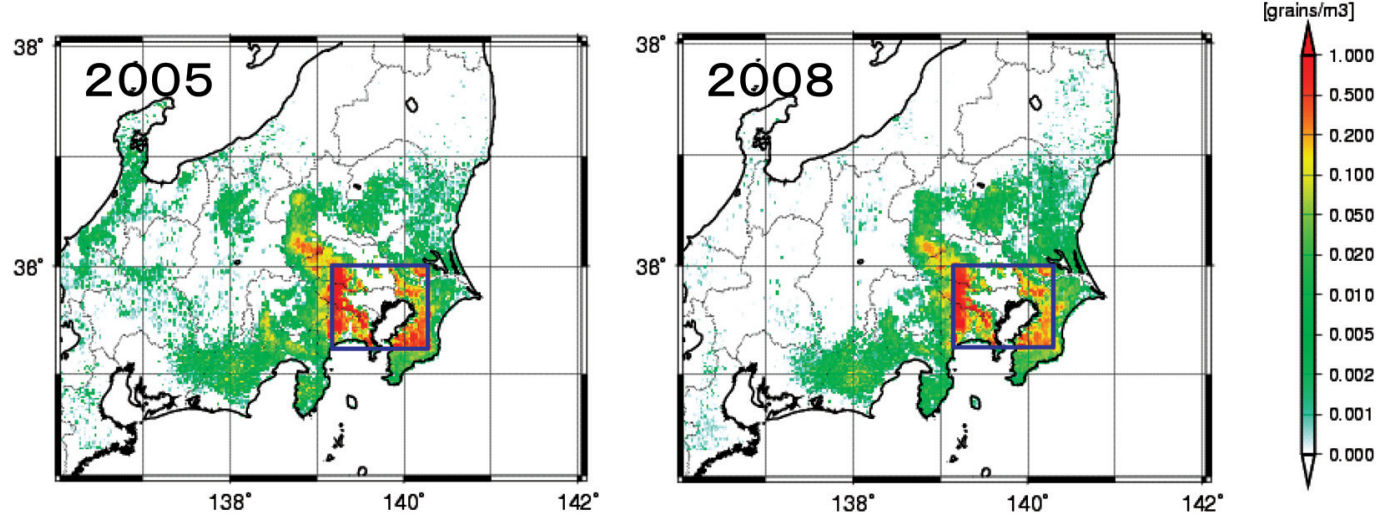

図-4. 広域首都圈領域（図-1の青線で囲まれた矩形領域）を対象とした寄与濃度の推定結果
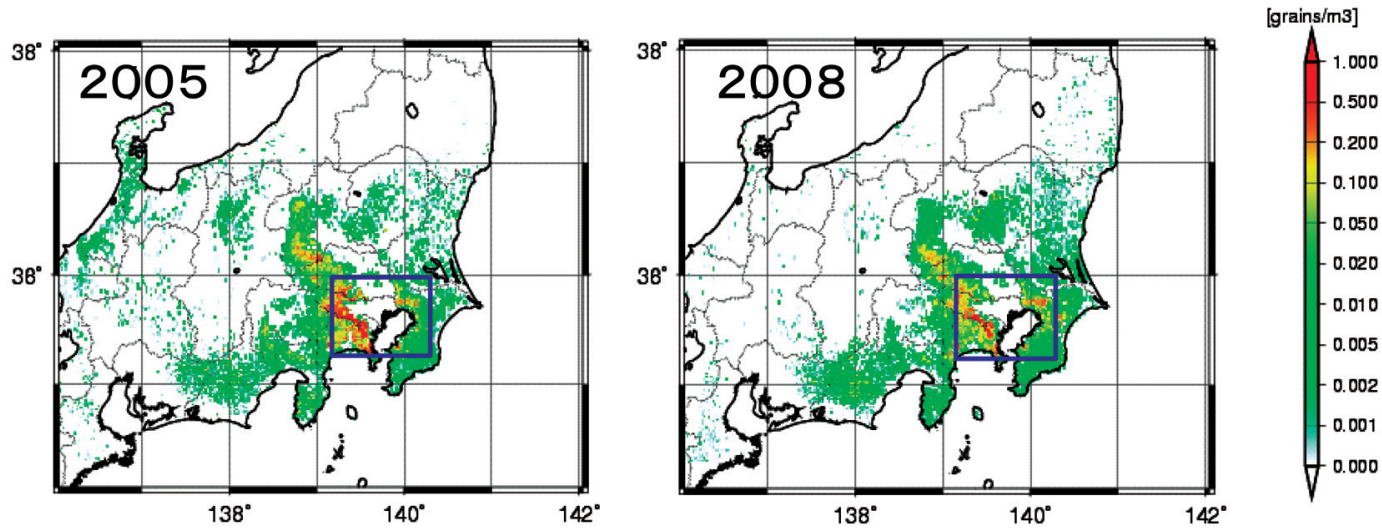

図-5. 広域首都圈領域（図-1の青線で囲まれた矩形領域）を対象とした人口分布を考慮した寄与濃度の推定結果

度の高い花粉放出源は東京都心を対象とした場合とはかな り異なるかもしれない。こうした問題を回避するには夕ー ゲット領域をより広げることが有効であると考えられる。 しかし，その場合，花粉放出源も含んでしまうので，寄与 濃度での評価には先に指摘したように問題が残る（図-4）。

一方，人口分布を考虑した寄与濃度を適用すればこの問 題は回避される（図-5)。さらに，この手法であれば，ター ゲット領域内に花粉放出源が含まれていても問題がないの で，ターゲット領域を任意に広げることが可能である。た
とえば関東地方全域に適用する，あるいは理論的には日本 全国を一度に対象とすることも可能である。また，曝露指 標はターゲット領域全体に居住する人口が浴びる花粉総量 の指標であるため, 花粉症対策としては花粉濃度を指標と する寄与濃度よりも人口分布を考慮した寄与濃度の方が客 観的指標であるとみなすことができよう。

第二は, 年によって結果の異なる可能性がある点である。 図-5では両年でさほど大きな違いはなかったが，千葉県方 面からの流入が 2008 年の方が多かった。他のシーズンで 
はより大きく結果が異なる可能性も想定される。そのシー ズンの風系, 雄花着花量の地域的偏り, 各放出源における 開花時期とその時期の風系との関係などが大きく関与する ためである。今回提示した手法による推定結果を用いて， 放出源対策を優先する地域を選定する際には，数年間の結 果を良く勘案したうえで，慎重に対応する必要がある。

本研究で使用した花粉飛散予報モデルの作成，改良に際 し, 開花時期の予測を行うサブモデルのパラメータ設定に, 野外におけるスギ雄花開花調査デー夕が不可欠であった。 開花調査を実施しデー夕を提供していただいた，千葉県農 林総合研究センター森林研究所の福島成樹氏，岩手県林業 技術センターの蓬田英俊氏, 秋田県農林水産技術センター 森林技術センターの佐藤博文氏，静岡県農林技術研究所森 林・林業技術センターの山本茂弘氏，群馬県林業試験場の 中村博一氏に深く感謝する。また，ダーラム型花粉捕集器 による花粉モニタリングデータを快く提供いただいた，遠 藤耳鼻咽喉科・アレルギークリニックの遠藤朝彦先生に深 く感謝する。さらに, 花粉飛散予報精度の検証に, 東京都 事業「とうきょう花粉ネット」(http://www.fukushihoken. metro.tokyo.jp/kanho/kafun/）で公開されている花粉濃度 観測デー夕を使用させていただいた。なお，本研究は，農 林水産省「先端技術を活用した農林水産研究高度化事業」 （現「新たな農林水産政策を推進する実用技術開発事業」） の「スギ雄花形成の機構解明と抑制技術の高度化に関する 研究」（課題番号：18004）によった。

\section{引用文献}

有沢雄三 (2000) スギ林からの花粉放出量の計測, 予測に関する研究. （スギ花粉症克服に向けた総合研究（第 I 期）成果報告書. 科学 技術庁研究開発局). 335-348.

馬場廣太郎・中江公裕（2008）鼻アレルギーの全国疫学調査 2008
(1998 年との比較)一耳鼻咽喉科医およびその家族を対象とし て. Progress in Medicine 28: 2001-2012.

堀口申作・斎藤洋三 (1964) 栃木県日光地方におけるスギ花粉症 Japanese Cedar Pollinosis の発見.アレルギー13: 16-18.

家原敏郎・宮本麻子 (2002) 全国のスギ・ヒノキ花粉発生源分布図の 作成. 日林学術講 113: 450 .

家原敏郎・宮本麻子・高橋義一（2000）関東地方におけるスギ・ヒノ キ花粉飛散予測高度化のための花粉発生源分布データセットの 作製。日林関東支論 51: 63-66.

金指達郎（2003）都市への花粉飛散をおこすスギ林の同定に関する研 究.（スギ花粉症克服に向けた総合研究（第 II 期）成果報告書. 文部科学省)。197-206.

金指達郎・横山敏孝 (2002) スギ雄花の休眠打破と開花に要する温度 条件. 日花粉誌 48: 95-112.

Kanazashi and Yokoyama (2005) The effect of alternating temperature on the rest break process of Cryptomeria japonica D. Don. J. For. Res. 10: 493-496.

林野庁 (2009) 森林・林業統計要覧 2009. 250 pp.

斎藤真己（2008）無花粉スギの開発状況と今後の展望. 森林科学 54: $17-20$.

斎藤洋三 (1999) スギ花粉症一過去・現在・未来一. 日花粉誌 45: 5562.

鈴木基雄（2003）スギ花粉飛散モデルの精度向上と総合的予報に関す る研究.（スギ花粉症克服に向けた総合研究（第 II 期）成果報告 書. 文部科学省). 184-196.

鈴木基雄（2007）最近の花粉飛散予報システムとは？Q and A でわか るアレルギー疾患 $3: 577-579$.

平 英彰 (2006) スギ花粉症を取り巻く諸問題一スギ雄性不稔個体の 利用と開発一. 林木の育種 220: 1-3.

平 英彰・寺西秀豊・劍田幸子（1993） スギの雄性不稔個体につい て. 日林誌 $75 ： 377-379$.

田島正啓 (2001) 林木育種研究と最近の成果一林木育種センターを中 心として一. 育種学研究 3: 103-108.

津田京子（2007）今後の花粉発生源対策の推進方策について一花粉発 生源対策プロジェクトチーム検討報告一. 林木の育種 225: 17-18.

統計情報研究開発センター（2005）平成 12 年度国勢調査及び平成 13 年度事業所・企業統計調査等のリンクによる地域メッシュ統計 (CD-ROM)

横山敏孝・金指達郎（2001）花粉飛散予測のためのスギ林の雄花生産 量推定法. 日林関東支論 53: 137-138. 